\title{
Comparing South Korea and Italy's healthcare systems and initiatives to combat COVID-19
}

\author{
Ashwin Palaniappan ${ }^{1}$, Udit Dave ${ }^{2}$ and Brandon Gosine ${ }^{3}$
}

Suggested citation Palaniappan A, Dave U and Gosine B. Comparing South Korea and Italy's healthcare systems and initiatives to combat COVID-19. Rev Panam Salud Publica. 2020;44:e53. https://doi.org/10.26633/RPSP.2020.53

ABSTRACT Italy and South Korea have two distinctly different healthcare systems, causing them to respond to public health crises such as the COVID-19 pandemic in markedly different ways. Differences exist in medical education for both countries, allowing South Korean medical graduates to have a more holistic education in comparison to their Italian counterparts, who specialize in medical education earlier on. Additionally, there are fewer South Korean physicians per 1000 people in South Korea compared to Italian physicians per 1000 people in Italy. However, both countries have a national healthcare system with universal healthcare coverage. Despite this underlying similarity, the two countries addressed COVID-19 in nearly opposite manners. South Korea employed technology and the holistic education of its physician community, despite having a smaller proportion of physicians in society, to its advantage by implementing efficacious drive-through centers that test suspected individuals rapidly and with little to no contact with healthcare staff, decreasing the possibility of transmission of COVID-19. Conversely, Italy is presently considered the epicenter of the outbreak in Europe and has recorded the highest death toll of any country outside of mainland China. This is partially due to the reactionary nature of Italy's public health measures compared to South Korea's proactive response. The different healthcare responses of South Korea and Italy can inform decisions made by public health bodies in other countries, especially in countries across the Americas, which can selectively adopt policies that have worked in curtailing the spread of COVID-19 and learn from mistakes made by both countries.

Keywords $\quad$ Coronavirus infection; virus diseases; pneumonia, viral; pandemics; SARS virus; health systems.

\section{STRUCTURAL DIFFERENCES IN HEALTHCARE SYSTEMS}

There are stark differences between the Italian and South Korean healthcare systems which have caused them to respond to public health crises in markedly different ways. This is of importance to public health organizations in the Americas because it serves as a guideline for identifying efficacious policies. The Italian healthcare system provides universal coverage, funded primarily by national and regional taxation (1). A majority of care is provided free at the point of delivery. Copayments are collected for outpatient care and drug costs. The public sector accounts for $78.2 \%$ of total healthcare spending, and local governments are responsible for the establishment of healthcare services (1). The Italian National Health Service (INHS) provides comprehensive coverage, and local governments are mandated to provide "Livelli Essenziali di Assistenza," translating to "essential levels of care" and is colloquially abbreviated as 'LEAs' (2). The three main categories of healthcare services encompassing LEAs are: public health, community care, and hospital care (2). As a result of different levels of wealth across different regions, inequities are observed across Italian healthcare (1).

\footnotetext{
${ }^{1}$ Brown University, Providence, United States of America $\square$ Ashwin Palaniappan, ashwin_palaniappan@brown.edu

${ }^{2}$ Georgetown University, Washington, DC, United States of America
} 
Similarly, in South Korea, the government provides universal healthcare coverage (3). However, the South Korean system is highly reliant on private providers and patients face substantial out-of-pocket costs. Copayments of $20 \%$ are required for services under the single-payer health plan, and for uncovered procedures, patients are required to make full payments. Personal spending accounts for $89.1 \%$ of South Korean healthcare expenditures, highlighting the limited role of the government in addressing public health benchmarks (3). However, there is a ceiling on out-of-pocket payments, and discounts are provided on the basis of low income (3). The single insurer in the South Korean healthcare system is the National Health Insurance Service (NHIS) (4). All services, including long-term facility care, are paid for by the NHIS after claim reviews. South Korean individuals pay a copayment to their health service provider as well as a contribution to the NHIS. In return, they receive healthcare from their provider of choice while being covered under an NHIS health insurance policy, which reduces their out-of-pocket expenses (4).

Both Italy and South Korea present advanced health care systems that provide universal coverage to their residents at generally affordable costs. Both systems provide comprehensive care with a focus on public health and preventative medicine. The differences in each country's relative success at curtailing the spread of COVID-19, therefore, is likely attributable to differences in medical education systems and the utilization of mobilized technological innovations as well as demographic differences in the Italian and Korean populations.

\section{MEDICAL EDUCATION}

With 41 medical schools and 3500 annual graduates, South Korea has a drastically different medical education system from Italy (5). Medical education in South Korea begins with two years of premedical studies, centered on humanities. The next four years are devoted to a medical curriculum, which emphasizes theoretical concepts than practical applications (6). South Korean medical students rotate between clinical departments on a weekly basis, ensuring a near complete coverage of all the different specialties a Korean hospital has to offer. South Korea is also a leader with regard to the technology available to the medical students, namely in the widespread use of virtual dissections of human bodies (6). Although Italy's medical education is an equivalent six years; it is sectioned off into two three-year phases, with the first phase being nonclinical scientific education and the second phase being clinical and nonclinical training (7). A major demographic difference between the two nations is that, on average, there are 4.1 physicians per 1000 people in Italy, which is nearly double South Korea's 2.4 physicians per 1000 people (8). Italy is much better medically staffed, and there are policies implemented to regulate the supply of physicians in Italy through avenues such as national quotas, causing Italy to graduate fewer physicians annually than South Korea. Furthermore, Italy has advanced from offering unpaid residency programs with little central oversight to being governed by national goals for paid residency programs set by the National Observatory of Residency Schools. For instance, one goal is that within surgical residencies, Italian residents must perform at least 425 surgical operations with status as a first-operator in $1 / 3$ of those operations (9).

\section{CULTURE OF CARE}

Differences in medical education cause differences in the patient-physician relationship. There is a widespread culture of defensive medicine in Italy due to increased medical litigation, specifically medical malpractice suits (10). This suggests a decreasing trust in physician-patient relationships on a national level. The cornerstone of these suits is informed consent, where patients believe physicians did not appropriately explain medical interventions prior to gaining consent to perform the procedure. This has led to an increase in consent forms in clinics to shield physicians from culpability, detracting from a shared decision framework between patients and physicians. Italian jurisprudence also emphasizes this statute of informed consent to an extent where if a patient does not have complete knowledge of the situation, proceeding with a medical intervention is considered an injury to the patient's personal dignity (10). This poses significant issues in the cases of pandemics or catastrophic health events because the trust between a patient and physician becomes even more essential in order for patients to obtain effective healthcare services. Italian physicians have taken strides to rectify this fallibility through increased accountability of physicians, increased efficiency of the healthcare system, and providing more appropriate services for patients (10). Conversely, South Korea does not yet teach the patient-physician relationship in the medical education system. Due to national health insurance and government-driven health policy, South Korean physicians are not given freedom to practice self-governance in their relationships with patients (11). This stifles the capacity of medical professionalism, which is essential for building trust in the patient-physician relationship. Hospitals present competitive atmospheres focused on maximizing profits because patients may visit any clinic with referrals (12). This has consequences on trust in the patient-physician relationship because hospitals focus on recruiting physicians capable of attracting patients. Therefore, public perception of clinicians is that they are inferior to physicians staffed in hospitals (12). Patients believe they have sufficient access to primary care institutions and are uncertain when deciding on which institution to select for medical care (12). However, there is concern regarding limited hours offered by primary care providers on weekends and holidays (12). This reinforces South Korea's struggles due to an overlap in functions between clinics and hospitals, which in turn weakens the function of primary care (12). The Korean healthcare system is predicated on efficiency to reduce costs so when individuals who may be infected with COVID-19 turn to the emergency room instead of their primary healthcare providers for testing, especially in cases with mild symptoms, disproportionate burdens are placed on the emergency care system and subsequently the national healthcare system.

Italy's physician demographic notably has the highest share of physicians over 55 years of age and follows the general European trend in which more physicians opt for specialist positions rather than serving as general practitioners (13). Physician demographics may change significantly when a large wave of physicians retire in Italy. Elderly populations above 65-years-old comprise $23 \%$ of the Italian population, meaning more Italians are prone to illnesses that differentially affect those with underlying conditions (14). Conversely, South Korea's elderly comprise $15 \%$ of the national population. There is an exacerbated need in Italy due to an increased vulnerable patient population and a 
higher likelihood that Italian physicians may become infected with the disease and present acute symptoms (14).

\section{PREVENTATIVE PUBLIC HEALTH MEASURES}

In an effort to combat COVID-19, Italy and South Korea have turned to their federal governments to implement public health measures. Following South Korea's first reported case of COVID19, the South Korean national government has improved at creating protocols to identify new cases and prevent spread, leading to a decrease in infection incidence rate (15). Since the first reported case in South Korea, the number of known cases has grown to 8413 as of March 18, 2020 (16). In response to this increase, South Korea implemented various forms of social distancing including cancellation of social events, increased restriction of public transportation, and suspension of school activities (17). In addition to social distancing, South Korea has implemented innovative testing for COVID-19: particularly drive-through COVID-19 testing centers (18). These new testing centers are remarkably efficient and are able to test an individual in ten minutes. They have empowered South Korea to test approximately 250000 individuals since January $20^{\text {th }}$. Results are sent to patients by text the day after testing, after which positive patients are quarantined to prevent any further spread (18). These patients then use a phone application to update the government on their condition (19). South Korea has opened 43 of these drive-through testing stations across the country (15), which has led to a testing rate of 3692 tests per million (20).

In contrast, Italy has taken an approach to the spread of COVID-19 that is more reactive. Italy's testing rate is approximately 826 people per million (20), and this low testing rate has allowed the total number of reported cases to reach 31 506 as of March 18, 2020 (16). Furthermore, due to an increasing number of cases, the Italian government placed the entire country on a total lockdown in hopes of containing COVID-19 and preventing further spread (21). However, this nationwide lockdown faced resistance from Italian citizens, particularly prisoners. Inmates led riots in prisons in reaction to being unable to see family who were placed on lockdown (21). Failing to implement proactive measures to combat COVID-19 and only implementing reactive strategies to stop spread has led to over 2000 deaths from COVID-19 in Italy as of March 18, 2020 (16). Italy is running out of beds in intensive care units, and hospitals are forced to implement a triaging system to determine which patients to use their limited resources on to bring about the best outcomes from a population-wide standpoint (22). The pandemic has also been particularly taxing on physicians in Italy, who are working extended hours to fight COVID-19 and warn that Italy's healthcare system is close to collapsing (22).

South Korea has been more successful than Italy in preventing the spread of COVID-19 because of experience with prior outbreaks, namely the 2015 Middle Eastern Respiratory Syndrome (MERS) outbreak (18). South Korea prevented a comprehensive spread of MERS in 2015, but the country quickly implemented the idea of drive-through clinics afterwards. These drive-through clinics make the testing process faster, keep clinicians safe, remove ten minutes from cleaning rooms, and shorten length of testing in half (18) Furthermore, South Korea is considered one of the most educated countries in the world. The Organization for Economic Cooperation and Development (OECD) states that of 51.5 million people in South Korea, $70 \%$ of 24 -to-35-year-olds have completed college and graduate programs, giving it an advantage in combating COVID-19 (23). Another advantage is the fact that it boasts the fastest internet in the world, with broadband speed four times that of the United States. (24). These faster internet speeds help clinicians process tests and distribute results faster than physicians in other nations. Another major advantage is the culture of wearing surgical masks, learned from MERS (25).

Due to past experiences, South Korea was well prepared for the COVID-19 outbreak, allowing it to have a high testing rate. The differences in attitudes and policies explain the stark difference in outcomes for the citizens between South Korea and Italy. The public health community is urged to learn from the successes of South Korea to lessen COVID-19 fatalities and regulate contagion spread. These takeaways are crucial when informing governments across the Americas about how to combat COVID-19. Pan-American countries should focus on supporting citizens during social isolation and making testing products available to the general public through subsidies to ensure they are low-cost or free-of-cost as in South Korea. Furthermore, public health groups should continue to disseminate real-time statistics and suggestions while simultaneously mitigating spread of misinformation and sensationalized anecdotes.

\section{Conflict of interest. None declared.}

Disclaimer. Authors hold sole responsibility for the views expressed in the manuscript, which may not necessarily reflect the opinion or policy of the RPSP/PAJPH or the Pan American Health Organization (PAHO).

\section{REFERENCES}

1. Ferré F, de Belvis AG, Valerio L, Longhi S, Lazzari A, Fattore G, et al. Italy Health system review. Health Syst Trans. 2014;16(4).

2. Torbica A, Fattore G. The "Essential Levels of Care" in Italy: when being explicit serves the devolution of powers. Eur J Health Econ. 2005;6:46-52.

3. Kwon S, Lee T, Kim C. Republic of Korea Health System Review. Health Syst Trans. 2015;5(4).

4. Seong SC, Kim Y, Khang Y, Park JH, Kang H, Lee H, et al. Data Resource Profile: The National Health Information Database of the National Health Insurance Service in South Korea. Int J Epidemiol. 2017;46(3):799-800.

5. Kim KJ, Kee C. Reform of medical education in Korea. Med Teach. 2010;32(2):113-117.
6. Krueger R. Medical education in Korea from a German student's perspective. Korean J Med Educ. 2019;31(1):83-7

7. Organization for Economic Cooperation and Development. Health Workforce Policies in OECD Countries: Trends in Medical Education and Training in Italy. OECD; 2016. Available at: https:// www.oecd.org/health/health-systems/OECD-Health-WorkforcePolicies-2016-Doctors-Italy.pdf

8. The World Bank. Physicians (per 1,000 people). Available at: https: / data.worldbank.org/indicator/SH.MED.PHYS.ZS. Accessed March 17, 2020.

9. Turillazzi E, Neri M. Informed consent and Italian physicians: change course or abandon ship--from formal authorization to a culture of sharing. Med Health Care Philos. 2015;18(3):449-453. 
10. Montorsi M, De Manzini N. The General Surgery Residency Program in Italy: a changing scenario. Updates Surg. 2019;71:195-6.

11. Kim S, Choi S. The Medical Professionalism of Korean Physicians: Present and Future. BMC Med Ethics. 2015;16:56-7.

12. Ock M, Kim JE, Jo MW, Lee HJ, Kim HJ, Lee JY. Perceptions of primary care in Korea: a comparison of patient and physician focus group discussions. BMC Fam Pract. 2014;15:178-185.

13. Healthcare personnel statistics - physicians. Available at: https:// ec.europa.eu/eurostat/statistics-explained/index.php/ Healthcare_personnel_statistics_-_physicians\#Healthcare_personnel. Accessed March 17, 2020.

14. Population Reference Bureau. Countries With the Oldest Populations in the World [Internet], 2019. Available at: https://www.prb. org/countries-with-the-oldest-populations/ Accessed April 13, 2020.

15. Normile D. Coronavirus cases have dropped sharply in South Korea. What's the secret to its success? Sciencemag. March 17, 2020. Available at: https://www.sciencemag.org/news/2020/03/ coronavirus-cases-have-dropped-sharply-south-korea-whatssecret-its-success

16. Johns Hopkins Coronavirus Resource Center. Coronavirus COVID19 Global Cases by the Center for Systems Science and Engineering. Available at: https://coronavirus.jhu.edu/map.html.

17. Shim E, Tariq A, Choi W, Lee Y, Chowell G. Transmission potential of COVID-19 in South Korea. Int J Infect Dis. 2020;93:339-44. doi: 10.1016/j.ijid.2020.03.031 [Epub ahead of print].

18. Kuhn A. South Korea's Drive-Through Testing For Coronavirus Is Fast - And Free. NPR, March 13, 2020. Available at: https:// www.npr.org/sections/goatsandsoda/2020/03/13/815441078 / south-koreas-drive-through-testing-for-coronavirus-is-fast-and-free

19. Harrison B. South Korea proves pandemic response requires more than money. PBS March 13, 2020. Available at: https://www.pbs. org/newshour/show / south-korea-proves-pandemic-responserequires-more-than-money\#transcript.

20. Sepkowitz K. Why South Korea has so few coronavirus deaths while Italy has so many. CNN, March 17, 2020. Available at: https:/ /www. cnn.com/2020/03/16/opinions/south-korea-italy-coronavirussurvivability-sepkowitz/index.html

21. Di Donato V, Reynolds E, Picheta R. All of Italy is in lockdown as coronavirus cases rise. CNN, March 13, 2020. Available at: https:// www.cnn.com/2020/03/09/europe/coronavirus-italy-lockdownintl/index.html

22. Horowitz J. Italy's Health Care System Groans Under Coronavirus a Warning to the World. NYT, March 12, 2020. Available at: https:// www.nytimes.com / 2020/03/12/world / europe/12italycoronavirus-health-care.html.

23. Mani D, Trines S. Education in South Korea. World Education News and Reviews. 2018. Available at: https://wenr.wes.org/2018/10/ education-in-south-korea. Accessed April 12, 2020.

24. Sutter J. Why Internet connections are fastest in South Korea. CNN, Mar 31, 2010. Available at: https://www.cnn.com/2010 /TECH/03/31/broadband.south.korea/index.html.Accessed April $12,2020$.

25. Friedman U.Face Masks AreIn. The Atlantic,Apr 2,2020; Available at: https://www.theatlantic.com/politics/archive/2020/04/americaasia-face-mask-coronavirus/609283/. Accessed April 12, 2020.

Manuscript received on 18 March 2020. Revised version accepted for publication on 12 April 2020.

\section{Comparación de los sistemas de salud de Corea del Sur e Italia y las iniciativas para combatir la COVID-19}

RESUMEN

Palabras clave
Italia y Corea del Sur tienen dos sistemas de atención sanitaria claramente diferentes, lo que hace que respondan a crisis de salud pública como la pandemia por COVID-19 de maneras marcadamente distintas. Existen diferencias en la educación médica de ambos países, lo que permite a los graduados de medicina de Corea del Sur tener una educación más holística en comparación con sus homólogos italianos, que siguen una especialización médica de manera más temprana. Además, en Corea del Sur hay menos médicos por cada 1000 personas en comparación con Italia. Sin embargo, ambos países tienen un sistema nacional de salud con cobertura universal. A pesar de esta similitud subyacente, los dos países abordaron la COVID-19 de maneras casi opuestas. A pesar de contar con una proporción menor de médicos en la sociedad, Corea del Sur empleó la tecnología y la educación holística de su comunidad médica a su favor al implementar centros de examen de personas con sospecha de infección sin descender del automóvil, que permitían una atención rápida y con poco o ningún contacto con el personal de salud, lo que disminuyó la posibilidad de transmisión de la enfermedad. Por el contrario, Italia es considerada actualmente el epicentro del brote en Europa y ha registrado el mayor número de muertes que cualquier otro país fuera de la China continental. Esto se debe en parte a la naturaleza reactiva de las medidas de salud pública de Italia en comparación con la respuesta proactiva de Corea del Sur. Las diferentes respuestas sanitarias de Corea del Sur e Italia pueden orientar las decisiones que deben tomar los organismos de salud pública de otros países, especialmente en la Región de las Américas, que pueden adoptar selectivamente políticas que han funcionado para reducir la propagación de la COVID-19 y aprender de los errores cometidos por ambos países.

Infecciones por coronavirus; virosis; pandemias; virus del SRAS; sistemas de salud. 


\section{Comparação entre os sistemas de saúde da Coreia do Sul e da Itália e iniciativas para combater a COVID-19}

RESUMO A Itália e a Coreia do Sul têm dois sistemas de saúde distintos, o que os leva a responder a crises de saúde pública, como a pandemia COVID-19, de formas marcadamente diferentes. Existem diferenças na educação médica dos dois países, permitindo que os médicos sul-coreanos tenham uma educação mais holística em comparação com os seus homólogos italianos, que seguem uma especialização médica mais cedo. Além disso, há menos médicos por 1000 pessoas na Coreia do Sul do que em Itália. No entanto, ambos os países têm um sistema nacional de saúde com cobertura de saúde universal. Apesar desta semelhança subjacente, os dois países abordaram a COVID-19 de maneiras quase opostas. Apesar de ter uma proporção menor de médicos na sociedade, a Coreia do Sul utilizou a tecnologia e a educação holística de sua comunidade médica a seu favor, implementando centros de rastreio para pessoas com suspeita de infecção sem sair do carro, o que permitiu cuidados imediatos e pouco ou nenhum contacto com o pessoal de saúde, diminuindo assim a possibilidade de transmissão da COVID-19. Por outro lado, a Itália é atualmente considerada o epicentro do surto na Europa e tem registrado o maior número de mortes de qualquer país fora da China continental. Isto deve-se em parte à natureza reactiva das medidas de saúde pública da Itália em comparação com a resposta pró-ativa da Coreia do Sul. As diferentes respostas de saúde da Coreia do Sul e da Itália podem informar as decisões das agências de saúde pública de outros países, especialmente da Região das Américas, que podem adoptar seletivamente políticas que tenham funcionado na redução da disseminação da COVID-19 e aprender com os erros cometidos por ambos os países. 